\title{
Development Status and Countermeasures of Intelligent Manufacturing in Xi'an
}

\author{
Duan ZHENG \\ Xi'an International University \\ Xi'an, China \\ e-mail: zhengduan@xaiu.edu.cn
}

\begin{abstract}
Based on the development status of intelligent manufacturing in $\mathrm{Xi}$ 'an ,this paper analyses intelligent manufacturing environment of $\mathrm{Xi}^{\prime}$ an using SWOT-PEST analysis method and puts forward the development countermeasures of $\mathrm{Xi}$ 'an intelligent manufacturing from two angles of government and enterprises. It can further enhance technological innovation strength represented by intelligent manufacturing of Xi'an, play the advantages of Xi'an In the Silk Road Economic Belt Construction, upgrade the development level of new generation of information technology industry of Xi'an City.
\end{abstract}

Keywords-intelligent manufacturing; Xi'an; collaborative innovation

\section{INTRODUCTION}

The manufacturing industry is the main body of the social entity economy, and it is the key field of technological innovation and supply side structural reform. With the profound change of global manufacturing pattern, as the main direction of the 2025 China manufacturing, intelligent manufacturing is strategic choice of following a new round of technological revolution and the industrial revolution, reshaping the new advantage of manufacturing industry and improving the competitiveness in the international market, building manufacturing powerhouse. It has great significance to speed up the supply side structural reform, implement of intelligent manufacturing transformation and promote the industry towards high-end development. With the With the release and implementation of "intelligent manufacturing planning (2016-2020)" "Intelligent Manufacturing Engineering Implementation Guide (2016-2020)" " intelligent manufacturing national standard system construction guide (2015 Edition) " policy, intelligent manufacturing pilot demonstration of special operations, intelligent manufacturing and other special action to promote the continuous improvement of local government support policies and gradually improve, China has further optimized the policy environment for the development of intelligent manufacturing, consolidate the basis of development, stimulated the endogenous power. As a bridgehead for the development of the western region of Xi'an, how to make use of their own resources, the rational and rapid development of intelligent manufacturing industry, has great economic significance.

\section{THE THEORETICAL BASIS OF INTELLIGENT MANUFACTURING}

Intelligent manufacturing is the integration of the new generation of information and communication technology and advanced manufacturing technology based on depth, throughout all aspects of design, production, management, service and other manufacturing activities, the new mode of production has the function of self perception, self-learning, self decision and self adaptive execution, etc.. The research of intelligent manufacturing abroad mainly focuses on intelligent design, intelligent manufacturing, intelligent manufacturing services, intelligent management and so on. The intelligent manufacturing research in china focuses on intelligent manufacturing theory, intelligent manufacturing and business related research, intelligent manufacturing and industry related research, intelligent manufacturing and management innovation and corporate social responsibility related research.

\section{DEVELOPMENT OF INTELLIGENT MANUFACTURING IN XI'AN}

$\mathrm{Xi}$ 'an has a long history and splendid culture which is famous in the world, also is an important national scientific research, education and industrial base in the field of manufacturing technology, innovation ability. It has become an important carrier of world famous enterprises to invest in the west. Xi'an has a number of leading technologies and enterprises in the field of intelligent manufacturing, equipment manufacturing industry is the pillar industry of Xi'an industry. In 2015, Xi'an was named as one of the first batch of 40 key contact cities to run the national industry. As of now, Xi'an has a number of enterprises have been identified as the Ministry of intelligent manufacturing pilot demonstration projects such as Xi'an aircraft industry (Group) Co., Ltd., Xi'an Shaangu Limited by Share Ltd., AVIC Xi'an Flight Automatic Control Research Institute, Shaanxi Fashite gear Co Ltd, Xi'an ZTE Terminal Technology Co. Ltd. Many projects in Xi'an set up a model of intelligent manufacturing for example Xi'an Shaangu power equipment intelligent cloud service platform, XAC collaborative development cloud manufacturing platform, Xi'an ZTE intelligent terminal, intelligent manufacturing, intelligent manufacturing Shaanxi fast transmission, AVIC Xi'an Flight Automatic Control Research Institute of micro inertial devices, intelligent manufacturing, BYD's high-end smart terminal manufacturing projects. Autonomous core 
robot Qin of Xi'an aerospace precision electromechanical Research Institute for the transformation and upgrading of

the manufacturing sector provides an important equipment.

TABLE I. SWOT-PEST ANALYSIS OF INTELLIGENT MANUFACTURING DEVELOPMENT IN XI'AN

\begin{tabular}{|c|c|c|c|c|c|}
\hline \multicolumn{2}{|c|}{ SWOT } & Political & Economic & Social & Technology \\
\hline \multirow[b]{2}{*}{ 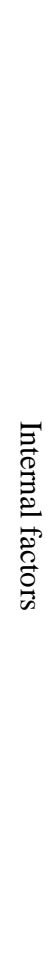 } & 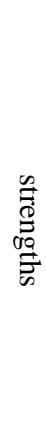 & $\begin{array}{l}\text { (1)Xi'an municipal government } \\
\text { issued a document to promote the } \\
\text { development of intelligent } \\
\text { manufacturing and regulations } \\
\text { (2)State and local governments } \\
\text { attach great importance to actively } \\
\text { guide and vigorously promote the } \\
\text { development of intelligent } \\
\text { manufacturing }\end{array}$ & $\begin{array}{l}\text { (1) State and local } \\
\text { governments give } \\
\text { intelligent } \\
\text { manufacturing } \\
\text { demonstration } \\
\text { enterprises more } \\
\text { financial support } \\
\text { (2) Xi'an financial } \\
\text { institutions update the } \\
\text { corporate financing } \\
\text { model to reduce } \\
\text { corporate financing } \\
\text { costs }\end{array}$ & $\begin{array}{l}\text { (1) Xi'an constantly improve the } \\
\text { function of urban infrastructure } \\
\text { (2) Intelligent manufacturing } \\
\text { equipment and advanced } \\
\text { technology are growing } \\
\text { popularity in key industries }\end{array}$ & $\begin{array}{l}\text { (1) Internet of things, "Internet } \\
\text { plus", mobile Internet and other } \\
\text { modern information technology } \\
\text { in the enterprise has been used } \\
\text { widely } \\
\text { (2) Intelligent robots and other } \\
\text { aspects of scientific research is } \\
\text { strong, enterprise innovation } \\
\text { has strong ability }\end{array}$ \\
\hline & 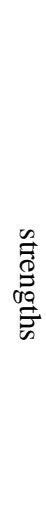 & $\begin{array}{l}\text { (1) the poor standard of intelligent } \\
\text { manufacturing and the unbalanced } \\
\text { development of industry } \\
\text { (2) the key technology and } \\
\text { equipment of intelligent } \\
\text { manufacturing are affected by } \\
\text { other countries } \\
\text { (3) support for small and medium } \\
\text { enterprises to improve the policy } \\
\text { support is not enough }\end{array}$ & $\begin{array}{l}\text { Industrial enterprises } \\
\text { in environmental } \\
\text { protection, logistics, } \\
\text { energy, tax, financing, } \\
\text { exchange rate and } \\
\text { other aspects of the } \\
\text { rigid costs continue to } \\
\text { rise, the rapid rise in } \\
\text { labor costs, } \\
\text { manufacturing profits } \\
\text { are squeezed }\end{array}$ & $\begin{array}{l}\text { (1) There are lack of intelligent } \\
\text { manufacturing top-level design } \\
\text { talent, cross-border talent supply } \\
\text { and training } \\
\text { (2) Manufacturing } \\
\text { mechanization, electrification, } \\
\text { automation, information coexist, } \\
\text { industry, enterprise development } \\
\text { is very uneven } \\
\text { (3) Enterprises generally } \\
\text { confused attitude towards } \\
\text { intelligent manufacturing, } \\
\text { intelligent manufacturing is } \\
\text { expected to benefit is not clear; } \\
\text { how to intelligent transformation } \\
\text { is no clear path can learn from. }\end{array}$ & $\begin{array}{l}\text { (1) Intelligent manufacturing } \\
\text { standards, software, network, } \\
\text { information security foundation } \\
\text { is weak, the new model of } \\
\text { intelligent manufacturing } \\
\text { maturity is not high } \\
\text { (2) The core technology of } \\
\text { high-end sensors, control } \\
\text { systems, industrial software, } \\
\text { industrial Internet and other } \\
\text { fields have yet to be broken }\end{array}$ \\
\hline \multirow{2}{*}{$\begin{array}{l}\frac{T}{x} \\
\overrightarrow{0} \\
\stackrel{0}{0} \\
\overrightarrow{0} \\
\stackrel{0}{0} \\
\stackrel{0}{0}\end{array}$} & 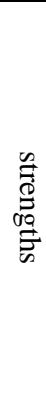 & $\begin{array}{l}\text { (1) The state has issued a } \\
\text { document to encourage the } \\
\text { development of the manufacturing } \\
\text { sector and fiscal and taxation } \\
\text { policies } \\
\text { (2) Xi'an continues to introduce } \\
\text { new initiatives for the } \\
\text { development of intelligent } \\
\text { manufacturing, through } \\
\text { government, industry } \\
\text { organizations, enterprises and } \\
\text { other collaborative }\end{array}$ & $\begin{array}{l}\text { Xi'an industrial } \\
\text { economy continued to } \\
\text { maintain steady } \\
\text { growth in good } \\
\text { momentum with an } \\
\text { increase of } 9.9 \%\end{array}$ & $\begin{array}{c}\text { Third party research and } \\
\text { development design, production } \\
\text { equipment, process management, } \\
\text { logistics and distribution, energy } \\
\text { management and other key } \\
\text { aspects of the intelligent level } \\
\text { continuously improve }\end{array}$ & $\begin{array}{l}\text { With the rapid development of } \\
\text { network infrastructure and } \\
\text { information and } \\
\text { communication technology, a } \\
\text { number of leading enterprises } \\
\text { have been formed in the fields } \\
\text { of high performance } \\
\text { computing, network } \\
\text { communication equipment, } \\
\text { intelligent terminals and } \\
\text { software }\end{array}$ \\
\hline & 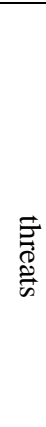 & $\begin{array}{l}\text { Xi'an is facing difficulties of } \\
\text { domestic and international } \\
\text { economic downward pressure } \\
\text { continues to increase, the } \\
\text { increasingly tight constraints on } \\
\text { resources and environment, } \\
\text { oversupply of traditional industrial } \\
\text { products, structural overcapacity } \\
\text { contradiction. }\end{array}$ & $\begin{array}{l}\text { (1) manufacturing } \\
\text { labor costs increased } \\
\text { significantly } \\
\text { (2) Intelligent } \\
\text { transformation } \\
\text { environment is } \\
\text { complex, the situation } \\
\text { is grim, the task is } \\
\text { arduous }\end{array}$ & $\begin{array}{c}\text { (1) Lack of intelligent } \\
\text { manufacturing model engineering } \\
\text { and international industry giants } \\
\text { and cross-border integration of } \\
\text { intelligent manufacturing } \\
\text { personnel } \\
\text { (2) Manufacturing industry } \\
\text { competitive pressures further } \\
\text { exacerbated, corporate profit } \\
\text { margins is difficult to guarantee } \\
\text { the continued funding of } \\
\text { intelligent manufacturing and } \\
\text { talent supply }\end{array}$ & $\begin{array}{l}\text { (1) the total supply capacity of } \\
\text { intelligent manufacturing } \\
\text { system is insufficient } \\
\text { (2) the protection of industrial } \\
\text { network security is not enough } \\
\text { (3) There are many weak links } \\
\text { in the field of intelligent } \\
\text { manufacturing, software, } \\
\text { control system, core } \\
\text { technology, key components } \\
\text { and other serious heteronomy. }\end{array}$ \\
\hline
\end{tabular}


In 2015, there are more than 1098 Industrial Enterprises above Designated Size in Xi'an, of which large enterprises accounted for only 41 , the number of above scale industrial enterprises accounted for only $3.7 \%$, large and medium sized industrial enterprises in 2015 achieved a total output value of 271 billion 893 million yuan, accounting for above scale industrial output value of $61.9 \%$, down 14.5 percentage points compared with 2011.However, Xi'an still attaches great importance to the intelligent manufacturing, it has gathered 69 companies in "intelligent terminal industry cluster" in $\mathrm{Hi}$ tech Zone and intelligent manufacturing equipment industry consist of intelligent energy-saving equipment manufacturing, smart grid equipment manufacturing and intelligent control systems and other industries in economic-technological development area. Yanliang District Chinese inaugurated the establishment of the railway construction of high-end equipment manufacturing base Xi'an also issued a "Xi'an implementation of the" China made 2025 "implementation of the opinions", set up a leading group of Xi'an manufacturing strong city list in 2015, issued the "opinions on a new round of technological transformation of enterprises" and set up a special technological innovation to guide capital by using information technology to transform and upgrade the existing industry, production, sales, finance, industry chain, pollution control and other aspects of intelligent management in 2016. However, in depth analysis of the status of intelligent manufacturing in Xi'an, there are the following coexistence such as a large number of small and medium-sized manufacturing level of low-end and a small number of advanced enterprises in the industry of high-end level coexist, the rapid growth of a large number of personalized intelligent automation needs and intelligent manufacturing suppliers response speed, R \& D capabilities, service levels are relatively lagging behind, the government actively guide and promote the rise of intelligent manufacturing enterprises and lack of funds coexist.

The environmental analysis of the development of intelligent logistics in Xi'an is shown in table I.

Through the analysis we can see that although there are still many problems in the development process of Xi'an intelligent manufacturing industry, Such as entrepreneurs by short-term profit driven, the pursuit of fast track, strategy consciousness is not strong, lack of long-term planning; technical level, quality consciousness is not strong, the 2 industrial foundation is weak; it is difficult to promote the management of change, management of poor foundation; the lack of high-end talent, talent and market demand of colleges and universities, collaborative ability is insufficient; the lack of high-end equipment, third party professional is not enough. There also faces some opportunities, it will further promote the healthy development of Xi'an intelligent manufacturing through the relevant departments of the strategic integration.

\section{THE DEVELOPMENT COUNTERMEASURE OF INTELLIGENT MANUFACTURING IN XI'AN}

In order to better develop the intelligent manufacturing industry in Xi'an, the government, enterprises and social forces should work hard from the following aspects:

\section{A. Foster Intelligent Manufacturing Ecosystem}

In order to rapidly develop the intelligent manufacturing industry, Xi'an municipal government can further improve the manufacturing industry policy from the macro point, promote manufacturing industry upgrading and promoting the manufacturing industry technological progress, optimize the manufacturing industry space layout and strengthen international cooperation and exchanges. Firstly, government should strengthen the overall planning from the capital, taxation, and strengthen innovation, play a double role, continue to promote technological upgrading and strong industrial base project in intelligent manufacturing enterprises demonstration effect. Secondly, government should promote the integration of industries. Cross border integration is the core competitiveness of intelligent strategy, will change the future of society, including not only the external integration, but also internal integration. Based on this, the government and enterprises should cooperate to further promote the integration development of manufacturing and Internet plus, Accelerate the implementation of Intelligent Manufacturing Engineering, promote the close cooperation and collaborative innovation of equipment, automation, software, information technology and other areas, further form an intelligent manufacturing ecosystem which takes intelligent manufacturing system integrator, jointly promoted by leading companies in various fields as the core, the leading enterprises in various fields to promote the joint, a number of specialized expertise in the field of subdivision depth involvement and deeply involved in a number of professional enterprises based on the field of subdivision. the government should further promote the industry $2,3,4$, reduce the burden on enterprises, improve the implementation of support policies, reduce administrative examination and approval, relax the industry access conditions, maximize enterprise vitality and creativity, innovate the enthusiasm of the relevant scientific and technical personnel.

\section{B. Accelerate the Training of Intelligent Manufacturing Personnel}

Intelligent manufacturing personnel training is the core, which is the most important problem faced by manufacturing enterprises. There are a large number of universities and scientific research institutes in Xi'an, which are rich in scientific and technological talents, and provide a solid scientific and technological foundation and talent pool for the development of intelligent manufacturing industry. However, in the context of intelligent manufacturing, the definition of intelligent manufacturing talented person and the organization structure of the enterprise, the layout of the equipment and so on are not the same, this requires the government to innovate intelligent manufacturing personnel training mechanism, strengthen the training of intelligent 
manufacturing personnel training, innovation and intelligent manufacturing personnel incentive mechanism, build intelligent manufacturing service platform from a macro perspective, flexible talent can be introduced, such as parttime talent, network office, etc.. Intelligent manufacturing enterprises should create a personalized mechanism to cultivate the enterprise internal talent from their own, so that people get a sense of hierarchy and direction. Universities and related training institutions should be based on the needs of manufacturing enterprises and innovate intelligent manufacturing personnel training mode.

\section{Optimize the Investment Environment of Intelligent Manufacturing Industry}

Xi'an is actively coordinating and solving the specific problems encountered in the production and operation of manufacturing enterprises, and enjoy all the preferential policies permitted by law and policy. In order to further accelerate the development of intelligent manufacturing, the government should expand the field of intelligent manufacturing industry investment, co-ordinate the support of intelligent manufacturing leading enterprises, establish manufacturing industry development funds, and actively expand the financing channels for manufacturing enterprises, reduce manufacturing costs. This will enable intelligent manufacturing enterprises to reduce production costs and actively carry out intelligent manufacturing innovation by using of its own funds to support funds.

\section{Intelligent Manufacturing Enterprises Should Continue to Strengthen Collaborative Innovation}

The two key words of intelligent manufacturing are transparency and fusion. Transparency is the opening of the entire manufacturing process to all manager, supplier and supervision department, it is to achieve full transparency of the process. Fusion is to communicate with each other, to achieve a dialogue between all intelligent devices, people and equipment, while the entire supply chain should be integrated consideration. In order to strengthen the intelligent manufacturing, enterprises should realize the information sharing, make full use of the big data to integrate the advantage resources among enterprises, and realize the intelligent optimization of the production technology and production process, It should be autonomous learning and active response on this basis, achieve intelligent identification, intelligent sensing, intelligent monitoring, intelligent scheduling, collaborate innovation in the industrial chain, enhance the ability of innovation and service.

\section{E. Promote Manufacturing Share Economic Model}

At present, most of the manufacturing enterprises in our country are small and medium-sized enterprises, and the financial strength of enterprises is weak. At the same time, some factories have very good equipment, but the utilization rate is very low; some enterprises just need to do a new part, spend money to buy a complete set of production equipment is not worthwhile. It can be used to share mechanism, share economic model of manufacturing is through the rent to buy, on time, according to a billing way, reduce the purchase cost of the equipment, so that SMEs can low cost, low threshold to use more high-quality manufacturing resources. And enhance the overall level of Intelligent Manufacturing in Xi'an by using the synergistic scale effect.

\section{CONCLUSION}

Just as the national manufacturing strategy advisory committee member $\mathrm{Qu}$ Xianming said: intelligent manufacturing early may not be suitable for all industries, should be based on advanced technology, good market prospects, production capacity of the industry, the former should promote human, quality, cost, energy and other aspects of demand analysis, from easy to difficult, quick projects and the industry to seek a breakthrough. Intelligent manufacturing does not need intelligent blind pursuit of high level, not the pursuit of unmanned, to maximize the economic benefits as the goal, in accordance with the "path of single point - production workshop - factory" step by step. As a starting point for the country to promote the strategy of opening up to the West and the construction of the Silk Road Economic Belt, Xi'an bears an irreplaceable key role in the Silk Road Economic Belt, it should also gradually promote the development of intelligent manufacturing. Xi'an vigorously develop the intelligent manufacturing industry relying on its own unique advantages, which has an important impact on improving the level of social development and promoting the rapid upgrading of the manufacturing industry. It can further enhance the scientific and technological innovation strength represented by intelligent manufacturing. With the acceleration of Xi'an intelligent manufacturing, Xi'an will reflect the more obvious advantages and play a greater role in Silk Road Economic Belt construction, further enhance the development level of a new generation information technology industry in Xi'an City.

\section{REFERENCES}

[1] Xi Chongbin. In the era of supply chain competition, what kind of intelligent logistics is needed in manufacturing industry? $[\mathrm{J}]$. logistics technology and application, 2016 (11).

[2] Lu Bingheng. Intelligent manufacturing and collaborative innovation [J]. China Science and technology industry, 2016 (10): 20-21.

[3] Wang Youfa, Zhou Xianzhong. Research and development trends of intelligent manufacturing at home and abroad [J]. China Science and Technology Forum, 2016 (4): 154-160.

[4] Wang Yuanyuan. Research status and future trend of intelligent manufacturing $[\mathrm{J}]$. industrial economics forum, 2016, (5): 530-537.

[5] Intelligent manufacturing development bottlenecks, Quanzhou measures followed [N]. Quanzhou business daily, 2016, 12.26. 